\title{
Hydrodynamic effects on the origin and quality of organic matter for bivalves: an integrated isotopic, biochemical and transplant study
}

\author{
G. Sarà* \\ Dipartimento di Biologia Animale, University of Palermo, Via Archirafi 18, 90123 Palermo, Italy
}

\begin{abstract}
Different hydrodynamic conditions can affect both the origin and the quality of organic matter available to bivalve molluscs. I chose 2 environments with very different hydrodynamics (a Mediterranean lagoon open to flow and a closed pond), but similar with regard to temperature, salinity, depth, wind exposure and algae coverage, to investigate this. The lagoon was characterised by active flow and bivalve molluscs, whereas the pond was closed off from the lagoon's main flow but characterised by mussel beds of the highest density ever observed in the western Mediterranean. Biochemical features, ${ }^{13} \mathrm{C}$ and ${ }^{15} \mathrm{~N}$ contents of particulate and sedimentary organic matter, and isotopic signatures of dominant organisms, were used as descriptors of the trophodynamics in both systems. In the lagoon, intense lateral drifting forces moved organic matter far from production sites, thereby depleting the water column of resuspended sedimentary organic matter. In the pond, winddriven conditions enhanced the coupling between the water column and the sediments, enriching the pond with resuspended sedimentary products. Integrating results, it was deduced that mussels in the pond could exploit, over time, organic matter produced in loco, continually rearranged in loco by means of wind-driven resuspension and consumed in loco with an efficiency able to sustain a massive secondary production. In contrast, under lagoon conditions, the benthic and pelagic habitats were uncoupled, so that each had its own independent status with its own dynamics and production. This reduced the suitability of this habitat for high levels of secondary production.
\end{abstract}

KEY WORDS: Physical factors $\cdot$ Food availability $\cdot$ Mollusc $\cdot \delta^{13} \mathrm{C} \cdot \delta^{15} \mathrm{~N} \cdot \mathrm{POM} \cdot \mathrm{SOM} \cdot$ Mediterranean

\section{INTRODUCTION}

Hydrodynamic processes remove, distribute, canalise and transfer the available organic matter pool through the biota (Emerson 1990, Sarà et al. 2006), redistributing it for biological consumption (Lenihan et al. 1996, Wildish \& Kristmanson 1997). In shallow aquatic habitats, organic matter fluxes are driven by hydrodynamic processes that determine the magnitude of food supply to consumers, depending on its origin and quality. Hydrodynamic factors determine the residence time of resuspended particles in the water column, thereby regulating the response of suspension feeders (Judge et al. 1992, Wildish \& Kristmanson 1997). Indeed, the flux of particles available to bivalves is a function of both horizontal advection and concentration of food particles in the boundary benthic layer. For every increase in the velocity of the water current, the resuspension rates of sedimentary materials from the bottom, in turn, also increase (Lenihan et al. 1996, Smaal \& Haas 1997). This enriches the water column with benthic products, thereby increasing the food supply for bivalves (Ekman et al. 1989). Nevertheless, lateral (i.e. horizontal) drifting movements of water masses can play a further role in controlling the features of the food supply to suspension feeders. If lateral drifting movements are intense, resuspended particles produced in loco can be relocated far from their production sites. This depletes the local water column of organic matter and can reduce the likelihood that 
sessile suspension feeders exploit resuspended benthic matter as a potential energy source for their growth as well, except for some resources stemming from the pelagic realm (Lenihan et al. 1996). Under oligotrophic regimes, benthic contribution from resuspension can play a further energetic role, apart from the pelagic, to elicit biological and ecological responses in suspension feeders, i.e. if it is not present, filter feeder response declines (Hicks et al. 2001, Steffani \& Branch 2003).

In the present paper, the effect of 2 different hydrodynamic conditions (as represented by 2 field experimental models: active flow with resuspension and lateral transport vs. non-active flow with only local resuspension) on the origin of organic matter and its biochemical availability to bivalves has been investigated. The main objective was to generalise on another aspect of the ecological response of filter feeders that were present in different natural hydrodynamic conditions as a priori assumptions (Judge et al. 1992). The hypothesis tested was whether 2 different hydrodynamic configurations influenced isotopic origin and biochemical quality of food supply and whether, by means of a transplant experiment, the isotopic patterns of food that was assimilated by bivalves were related to the origin of the food availability as a function of the different hydrodynamic typology. separated from it by an artificial wall ( 1.5 m width). The pond $\left(75000 \mathrm{~m}^{2}\right.$ and $\left.60000 \mathrm{~m}^{3}\right)$ is the same depth as the lagoon $(\sim 0.8 \mathrm{~m})$ and is closed off from the main water movements of the lagoon. Both the lagoon and pond are characterised by sand-muddy bottoms that are covered for the most part by large stands of the seagrass Cymodocea nodosa, while Cystoseira sp., Chaetomorpha linum (O.F. Müller) Kützing and Laurencia papillosa (C. Agardh) Greville are the dominant macroalgae on all hard substrata. The mussel Brachidontes pharaonis is only present in the pond, where it dominates all hard substrata (annual mean density of $9387 \pm 4366$ ind. $\mathrm{m}^{-2}$; Sarà et al. 2000, 2003).

Experimental assumptions and design. Three sectors of the lagoon and the whole pond were chosen to test the effect of different hydrodynamics on the origin and quality of organic matter, and ultimately to account for the occurrence of mussel beds in the pond and their absence in the lagoon (Fig. 1). Lagoon sectors and pond had similar fetches (Sarà et al. 1999), which suggested that chances of resuspension could be quite similar (La Loggia et al. 2004). Thus, they were representative of 2 different conditions: the lagoon of an open system with active flow conditions and lateral transport of resuspended particles, and the pond of a closed system with non-active flow conditions, local residence of resuspended particles and vertical turbulent mixing. The assumption of active hydrodynamics for the lagoon had been based on the 2-dimensional

\section{MATERIALS AND METHODS}

Study area. The study was carried out in the area of the Stagnone di Marsala Lagoon in Western Sicily: $37^{\circ} 52^{\prime} \mathrm{N}$, $12^{\circ} 28^{\prime} \mathrm{E}_{\text {; }}$ hereafter referred to as the lagoon (Fig. 1) between autumn 2003 and summer 2004. The lagoon is connected to the Mediterranean circulation by 2 apertures, is shallow (average depth $0.8 \mathrm{~m}$ ) and appears as a long ( $7 \mathrm{~km})$ and narrow $(\sim 1 \mathrm{~km})$ stream tube (Denny 1988) parallel to the coast. Internal tides $(\sim 30 \mathrm{~cm})$ control the hydrodynamics which, combined with advection/convection, allow the horizontal flow of waters (La Loggia et al. 2004). Since no freshwater input is present, nutrients are present in low concentrations in all sectors of the lagoon, and the trophic response, in terms of chlorophyll a (chl a) concentration $\left(\sim 1.0 \mu \mathrm{g} \mathrm{l}^{-1}\right)$, identifies the lagoon as oligotrophic (Sarà et al. 1999).

The man-made pond is located on the eastern side of the lagoon (Fig. 1) and is

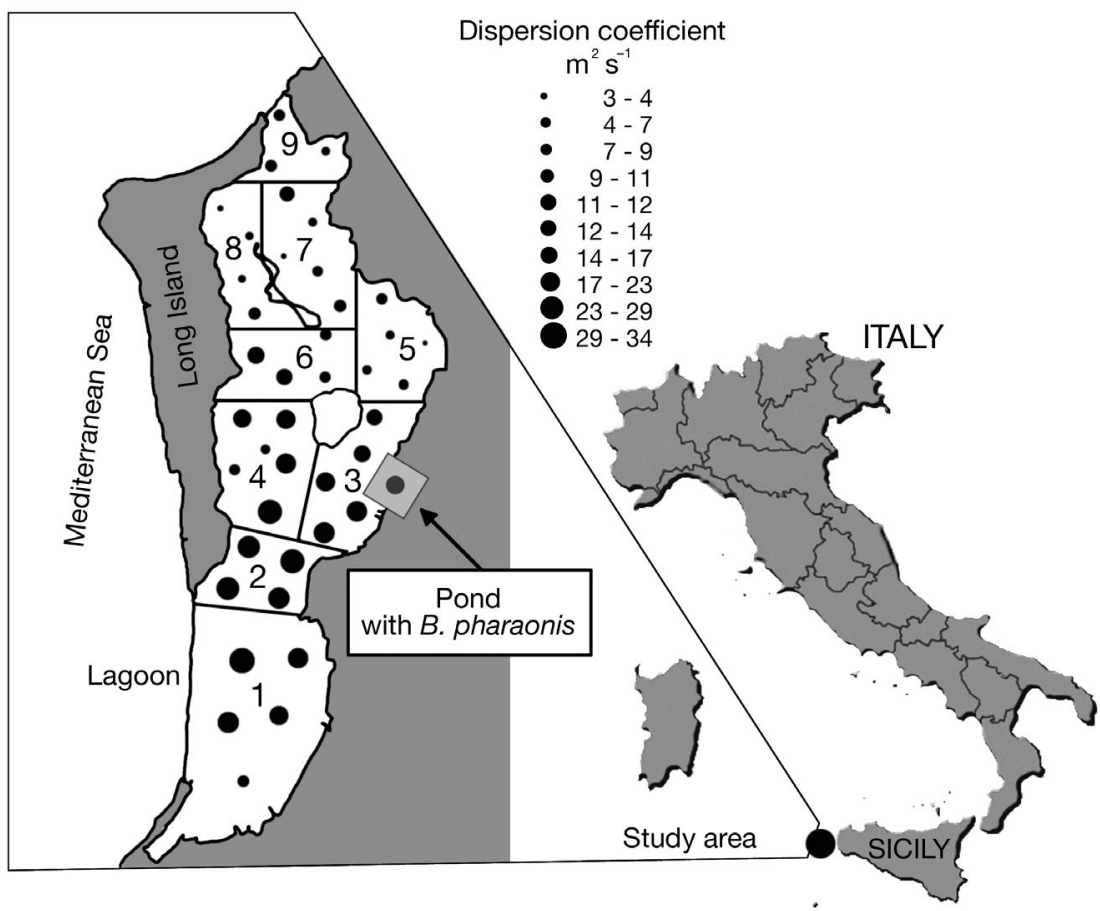

Fig. 1. Study area (modified from Fig. 3 in La Loggia et al. 2004) with the Brachidontes pharaonis pond. The scale of intertidal dispersion coefficient is reported 
advection dispersion transport model as described by La Loggia et al. (2004). With this model the amplitude of water mass exchange in a fixed point of the lagoon was estimated. The intertidal dispersion coefficient (IDC, $\mathrm{m}^{2} \mathrm{~s}^{-1}$ ), a measure that integrates data of water current velocities, wind shear stress, fetches etc. was calculated for different sectors of the lagoon (Fig. 1). The higher the IDC, the higher the lateral transport. Almost all sectors of the lagoon were characterised by water mass exchange (IDC $=14.0 \pm 6.9 \mathrm{~m} \mathrm{~s}^{-1}$ ). Therefore particles, once removed from the sediments, could be transported far from the production sites by lateral transport to adjacent areas, reducing their local residence time in the water column. By contrast, assumptions of non-active hydrodynamics made for the pond $(200 \times 300 \mathrm{~m})$ were as follows: (1) there was no connection with other adjacent environments, because it was a closed environment and (2) the energy in the pond was mainly represented by the daily pulsing of diurnal winds. Thus, once particles were resuspended from the sediments, they remained inside the pond, where they could be moved laterally for a maximum of $10 \mathrm{~m}$. This creates particular conditions of food supply, because wind energy and correlated movements of water masses function as a 'vacuum', able to extract sedimentary organic matter, which re-sinks locally due to the enclosure of the basin. This cycle of local resuspension-sedimentation is infinite, only correlated to wind and regulates the trophodynamics of the pond's water column.

Manipulative experiment. In autumn 2003, groups of stones of similar shape and size with Brachidontes pharaonis attached were collected from the pond and haphazardly thrown in the adjacent lagoon, in the 3 different areas where the trophic variables were also measured. The objective of this experiment was to compare the stable isotopic changes of the population living in the closed system to that of the transplanted population that was exposed to a set of new conditions in the lagoon. The experiment was planned to last of $12 \mathrm{mo}$, but had to be abandoned early after only $270 \mathrm{~d}$, because almost all transplanted $B$. pharaonis had died (see 'Results'). B. pharaonis were transplanted into the lagoon at the same initial average density that was found in the pond during autumn $(252 \pm 122$ ind. $400 \mathrm{~cm}^{-2}$; Sarà et al. 2000, 2003).

Sampling and laboratory analyses. Two sampling replicates of water and sediments were collected from each of the sites (6 from open and 2 from closed) on 2 sampling dates for each productivity period (low [summer 2004] and high [autumn 2003]; see below for details on experimental design). Water samples were collected using a Niskin bottle. Sediments were collected from cores obtained by driving PVC tubes (inner diameter $4.7 \mathrm{~cm}$ ) into the bottom, and primary sources such as seagrass and macroalgae were gathered by hand. Water samples were screened through a $200 \mu \mathrm{m}$ mesh net in order to remove large zooplankton and debris. Sub-samples (500 to $2000 \mathrm{ml}$ ) were filtered onto pre-washed, precombusted $\left(450^{\circ} \mathrm{C}, 4 \mathrm{~h}\right)$ and preweighed Whatman GF/F filters $(0.45 \mu \mathrm{m}$ nominal pore size). The top $0-1 \mathrm{~cm}$ layer of each core was immediately frozen at $-20^{\circ} \mathrm{C}$ and stored for later analysis. Water and sediments were each analysed in order to determine chloroplastic pigments ( $\mathrm{chl} a, \mu \mathrm{g} \mathrm{l}^{-1} \mathrm{~g}^{-1}$ ), carbohydrates $\left(\mathrm{CHO}, \mathrm{mg} \mathrm{l}^{-1} \mathrm{mg} \mathrm{g}^{-1}\right)$, proteins (PRT, $\mathrm{mg}^{-1} \mathrm{mg} \mathrm{g}^{-1}$ ) and lipids (LIP, $\mathrm{mg} \mathrm{l}^{-1} \mathrm{mg} \mathrm{g}^{-1}$ ) and their carbon $\left(\delta^{13} \mathrm{C}\right)$ and nitrogen $\left(\delta^{15} \mathrm{C}\right)$ stable isotopic compositions. Sedimentary and particulate chl a, proteins, carbohydrates and lipids were determined according to Fabiano et al. (2001) and Pusceddu et al. (2003). The sum of the 3 compound classes was reported as total particulate ( $\mathrm{POM}, \mathrm{mg} \mathrm{g}^{-1}$ ) and sedimentary ( $\mathrm{SOM}$, $\mathrm{mg} \mathrm{g}^{-1}$ ) organic matter. At least 10 samples of organisms (seagrass leaves, macroalgae, bivalves etc.) were collected. Pseudofaecal products from Brachidontes pharaonis individuals were collected after overnight evacuation by means of pipettes both from the pond and from the transplanted lagoon populations. After killing them, by freezing, the somatic flesh was dissected from the shell and rinsed with distilled water. Samples for carbon analysis were acidified in $1 \mathrm{~N} / 2 \mathrm{~N}$ $\mathrm{HCl}$, rinsed in distilled water, dried at $60^{\circ} \mathrm{C}$ for the time needed to reach a constant weight and ground with mortar and pestle. The isotopic analyses were performed using 2 replicates obtained from the pooling tissue of vegetal components, bivalves and mussel pseudofaeces of 10 different organisms. A Finnigan Delta-S isotope ratio mass spectrometer was used, and isotopic values were expressed in parts per thousand as deviations from standards (Peedee belemnite limestone for $\delta^{13} \mathrm{C}$ and nitrogen in air for $\delta^{15} \mathrm{~N}$ ).

Statistical analyses and elaboration. Four areas were chosen, 3 from the lagoon i.e. Areas 3, 4 and 6; (Fig. 1; see La Loggia et al. 2004 for details) and the whole pond as the fourth. The lagoon areas represented open conditions (active flow), while the pond was representative of closed conditions (non-active flow). All 4 areas were homogeneous with regard to depth, vegetal coverage and sediment type. Factors in the analysis were: 'hydrodynamic condition' (fixed, closed vs. open); 'area' (random, 4 levels nested within condition; 3 from the lagoon and the whole pond); 'site' (random, 2 levels, nested within area); 2 productivity 'periods' (fixed, 2 levels; low and high chl a concentrations [Sarà et al. 1999], to test if possible differences could be driven by changes in productivity) and 'times' (random, 2 levels, nested within period; high productivity sampling dates were 29 September and 24 October 2003 while low productivity sampling dates were 
5 July and 21 August 2004). Only one area at the 'closed' level (i.e. the pond) was sampled; therefore, this area was not completely orthogonal to levels of condition. An asymmetrical mixed-model ANOVA (Ceccherelli et al. 2005) was used with 2 sampling replicates for all variables. The required sums of squares for the asymmetrical components of these analyses were calculated according to Ceccherelli et al. (2005). As regards the manipulative experiment, an ANOVA was used to test seasonal isotopic differences between the transplanted and the natural mussels. Factors in the analysis were 'hydrodynamic condition' (fixed, closed vs. open), 'seasons' (fixed, 4 levels) and 'sites' (random, 2 levels, nested within area). For all ANOVA, Cochran's $C$-test was used to check the assumption of homogeneity of variances and, when necessary, data were log-transformed to remove heterogeneous variances (Underwood 1997).

In order to identify the most important carbon sources responsible for isotopic composition of POM and SOM, considered the direct trophic substrates for suspension feeders (Dame 1996), 2 isotope-multi source mixing models were performed (Phillips \& Gregg 2003, Sarà et al. 2003). In the model, POM and SOM isotopic signals were the targets, and isotopic signals of primary producers and secondary products were the main endmembers. Mixing models were carried out according to the background and assumptions of Phillips \& Gregg (2003), and ISOSOURCE (rel. 1.2; Phillips \& Gregg 2003) was used to calculate all of them.

\section{RESULTS}

\section{Origin of the organic matter in open vs. closed areas}

The carbon stable isotope composition of POM in the lagoon was significantly depleted with respect to the pond (Fig. 2a; Table 1). In contrast, in the lagoon the SOM carbon isotopic composition was notably more enriched than in the pond (ANOVA, p < 0.05; Fig. 2a; Table 1). The nitrogen in the POM in both systems (Fig. 2b) did not differ significantly (Table 2), while the SOM was significantly higher in the pond than the lagoon areas (Fig. 2b; Table 1). SOM and POM were differently composed, respectively, in the 2 systems (Table 2); the POM of the lagoon (Table 2) mainly comprised phytoplankton (64\%) and organic matter from sessile algae $(27 \%)$; the SOM was mainly composed of sessile algae $(57 \%)$ and Cymodocea (36\%). In the pond, bivalve ejections mainly contributed to the isotopic composition of POM (48\%) and secondarily to the phytoplankton (21\%). Sessile algae (47\%), sand microflora $(26 \%)$ and egestions $(25 \%)$ were the main determinants of the SOM isotopic composition.
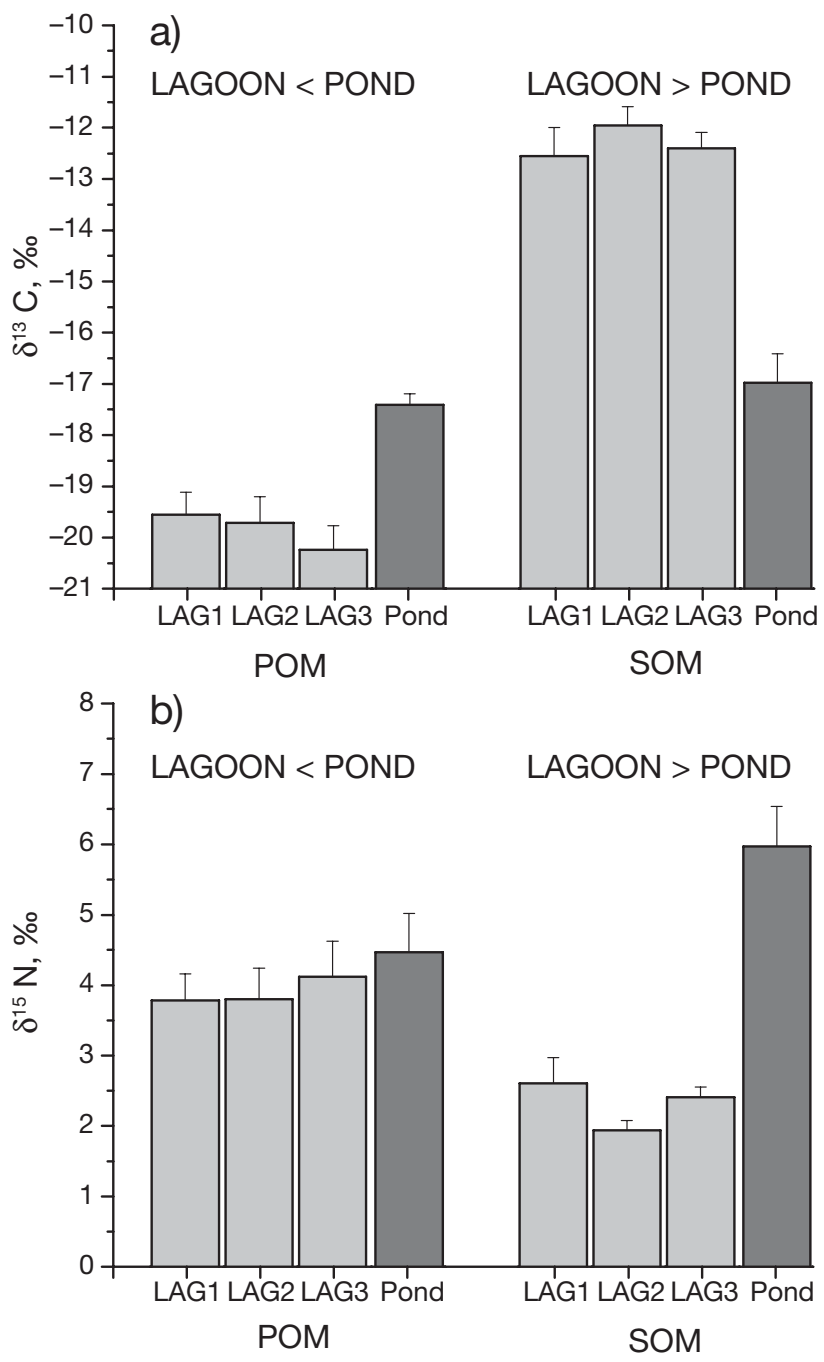

Fig. 2. Stable carbon $\left(\delta^{13} C_{;}\right.$a) and nitrogen $\left(\delta^{15} N_{;}\right.$b) composition of particulate (POM) and sedimentary (SOM) lagoon $\left(\mathrm{LAG}_{1}, \mathrm{LAG}_{1}, \mathrm{LAG}_{3}\right)$ vs. pond

\section{Quality and quantity of the organic matter in open vs. closed systems}

The concentration of suspended chl a was significantly higher (ANOVA, $\mathrm{p}<0.05$ ) in the pond than in the lagoon, while the contrary applied to the sediment (Table 3). Particulate proteins (Table 3) showed significantly higher values (ANOVA $\mathrm{p}<0.05$; Table 1 ) in the pond than in the lagoon, while the SOM pattern was different. About $4.5 \times$ more labile proteins were accumulated in the SOM of the lagoon than in the pond sediment (ANOVA, $\mathrm{p}<0.05$; Table 1). Carbohydrates in the pond POM (Table 3) were higher (ANOVA, p $<0.05$; Table 1) than in the lagoon, while carbohydrates showed higher (ANOVA, p $<0.05$; Table 1) concentrations in the lagoon than in the pond for the SOM. Lipids (Table 3) did not show significant 


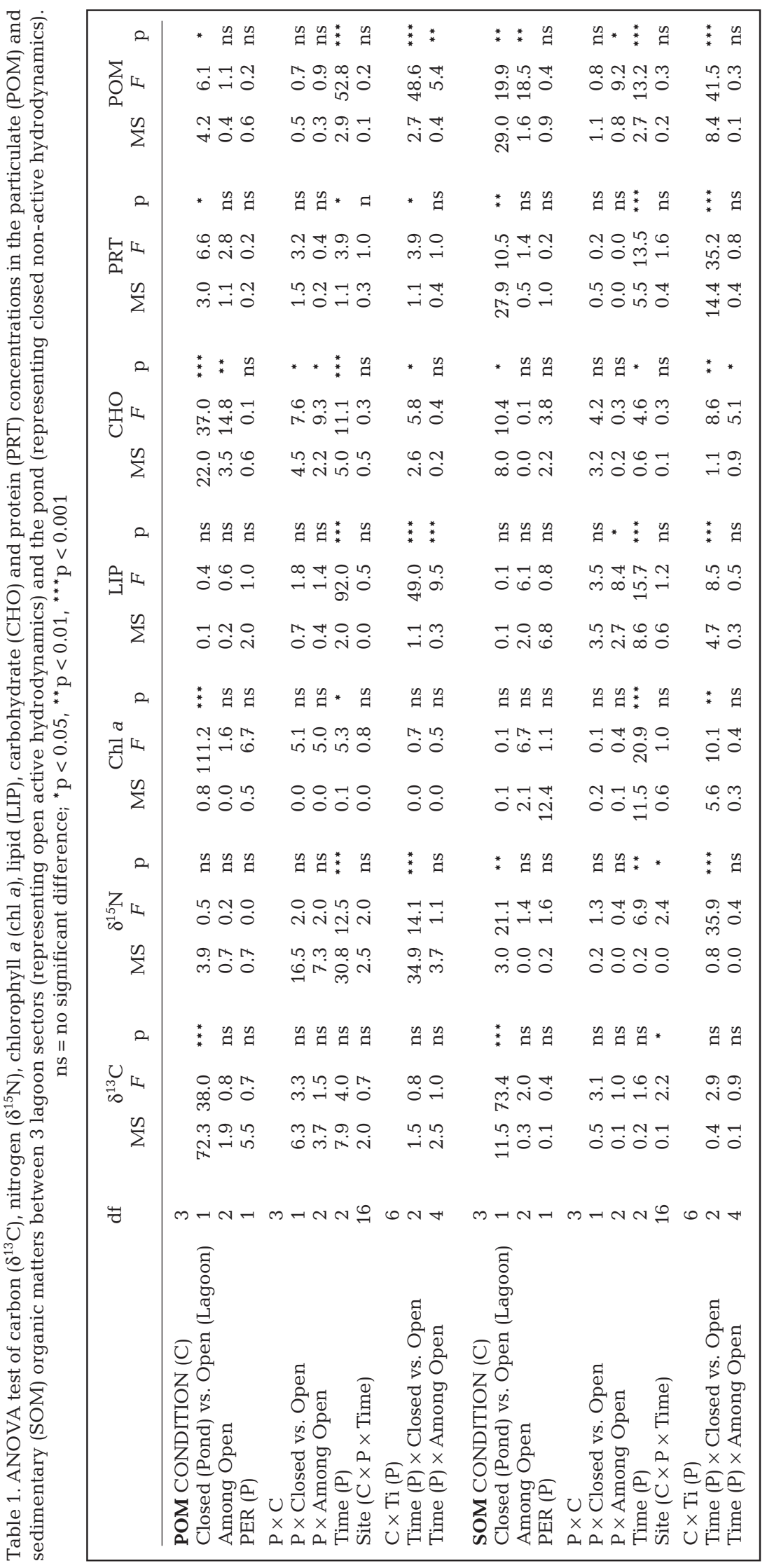

differences between the 2 different systems for both POM and SOM. The labile fraction of organic matter (Fig. 3a,b), expressed as a sum of proteins and carbohydrates, followed a similar pattern to that of proteins and carbohydrates with significantly higher values (ANOVA, $\mathrm{p}<0.05$; Table 1) in the pond and lower values in the lagoon; conversely, values in the sediments of the lagoon were up to 8 times higher than those of the pond.

\section{Response of suspension feeders to 2 different hydrodynamic conditions: a manipulative experiment}

Throughout the experiment, Brachidontes pharaonis continued its usual life cycle, i.e. reproducing and maintaining a stable population in the pond. In contrast, a very low number of individuals in the 3 transplanted populations developed their gonads and spawned; season after season, almost all of the individuals died, reducing their numbers from the initial density to only some rare individuals in all 3 open areas. At the moment of transplantation (Fig. 4a,b), B. pharaonis was characterized by $\delta^{13} \mathrm{C}$ of $14.3 \pm 0.5 \%$ and $\delta^{15} \mathrm{~N}$ of $7.5 \pm 0.8 \%$; in winter the $\delta^{13} \mathrm{C}$ of the pond population tended to deplete while the transplanted populations tended to enrich their initial values. The picture for $\delta^{15} \mathrm{~N}$ was similar for both, with a more marked tendency to depletion for the transplanted population (4.6 and $7.0 \%$, respectively). During the spring, the transplanted and the natural populations, the former depleting and the latter enriching its own $\delta^{13} \mathrm{C}$, converged towards similar values; while both enriched markedly in ${ }^{15} \mathrm{~N}$ during the summer, both tended to enrich in ${ }^{13} \mathrm{C}$ and deplete in their ${ }^{15} \mathrm{~N}$. On an annual basis, B. pharaonis' diet relied mainly on benthicderived products composed of its own egestion materials sand microflora and Cymodocea nodosa organic 
Table 2. Mixing models applied to particulate (POM) and sedimentary (SOM) organic matter in open (lagoon) and closed (pond) areas. Percentage values are ranked downwards (range $=1$ to 99th percentile). B. $p .=$ Brachidontes pharaonis; . nodosa $=$ Cymodocea nodosa

\begin{tabular}{|c|c|c|c|c|c|c|c|c|c|}
\hline OM sources & $\delta^{13} \mathrm{C}$ & $\delta^{15} \mathrm{~N}$ & $\%$ & Range & OM sources & $\delta^{13} \mathrm{C}$ & $\delta^{15} \mathrm{~N}$ & $\%$ & Range \\
\hline POM OPEN & & & & & POM CLOSED & & & & \\
\hline Phytoplankton & -22.7 & 4.7 & 64.3 & $60-71$ & B. p. egestions & -17.1 & 3.3 & 48.4 & $28-70$ \\
\hline Sessile algae & -16.0 & 1.8 & 27.0 & $20-32$ & Phytoaplankton & -22.7 & 4.7 & 21.0 & $1-40$ \\
\hline Drifting algae & -13.1 & 5.3 & 2.9 & $0-9$ & Sand microflora & -14.8 & 6.0 & 11.6 & $0-32$ \\
\hline C. nodosa & -6.0 & 2.4 & 2.9 & $0-8$ & Sessile algae & -18.8 & 7.4 & 9.9 & $0-27$ \\
\hline Sand microflora & -14.8 & 6.0 & 2.9 & $0-7$ & C. nodosa & -8.4 & 6.4 & 9.1 & $0-25$ \\
\hline SOM OPEN & & & & & SOM CLOSED & & & & \\
\hline Sessile algae & -16.0 & 1.8 & 57.0 & $57-57$ & Sessile algae & -18.8 & 7.4 & 46.5 & $46-47$ \\
\hline C. nodosa & -6.0 & 2.4 & 35.5 & $35-36$ & Sand microflora & -14.8 & 6.0 & 25.5 & $24-27$ \\
\hline Sand microflora & -14.8 & 6.0 & 4.0 & $2-6$ & B. $p$. egestions & -17.1 & 3.3 & 24.5 & $24-25$ \\
\hline Drifting algae & -13.1 & 5.3 & 3.5 & $1-6$ & C. nodosa & -8.4 & 6.4 & 3.5 & $3-4$ \\
\hline
\end{tabular}

Table 3. Trophic variables measured throughout the study areas (chl $\mathrm{a}=\mathrm{mg} \mathrm{l}^{-1}$ and $\mathrm{mg} \mathrm{g}^{-1}$; LIP, $\mathrm{mg} \mathrm{l}^{-1}$ and $\mathrm{mg} \mathrm{g}^{-1}=$ lipids; PRT, $\mathrm{mg} \mathrm{l}^{-1}$ and $\mathrm{mg} \mathrm{g}^{-1}=$ proteins; $\mathrm{CHO}, \mathrm{mg}^{-1}$ and $\mathrm{mg} \mathrm{g}^{-1}=$ carbohydrates; $\mathrm{POM}=$ particulate organic matter; $\mathrm{SOM}=$ sedimentary organic matter)

\begin{tabular}{|lcccccccc|}
\hline \multirow{2}{*}{ Area } & \multicolumn{2}{c}{ Chl $a$} & \multicolumn{2}{c}{ LIP } & \multicolumn{2}{c}{ PRT } & \multicolumn{2}{c|}{ CHO } \\
& Mean & \pm SE & Mean & \pm SE & Mean & \pm SE & Mean & \pm SE \\
\hline POM & & & & & & & & \\
Open 1 & 0.31 & 0.05 & 0.07 & 0.02 & 0.21 & 0.03 & 0.15 & 0.04 \\
Open 2 & 0.41 & 0.09 & 0.17 & 0.08 & 0.24 & 0.05 & 0.12 & 0.02 \\
Open 3 & 0.35 & 0.04 & 0.06 & 0.02 & 0.14 & 0.02 & 0.15 & 0.04 \\
All open & 0.36 & 0.04 & 0.10 & 0.03 & 0.20 & 0.02 & 0.14 & 0.02 \\
Closed & 0.74 & 0.04 & 0.09 & 0.01 & 0.26 & 0.01 & 0.24 & 0.02 \\
& & & & & & & & \\
SOM & & & & & & & & \\
Open 1 & 4.2 & 1.06 & 2.80 & 1.07 & 11.48 & 2.28 & 22.46 & 8.37 \\
Open 2 & 3.3 & 0.88 & 7.67 & 3.26 & 14.48 & 2.50 & 34.58 & 9.40 \\
Open 3 & 10.8 & 5.15 & 3.61 & 0.95 & 10.04 & 1.71 & 27.78 & 6.76 \\
All open & 5.9 & 1.80 & 4.37 & 1.17 & 11.91 & 1.28 & 27.69 & 4.75 \\
Closed & 2.6 & 0.28 & 1.85 & 0.14 & 2.78 & 0.67 & 2.81 & 0.36 \\
\hline
\end{tabular}

detritus in the pond. In the lagoon, however, B. pharaonis' diet relied mainly on pelagic-derived products, mainly phytoplankton, while drifting algae organic matter and sand microflora were secondary items.

\section{DISCUSSION}

\section{Causes of stable isotopic differences between pond and lagoon areas}

Differences in carbon and nitrogen compositions suggest that the origin of organic matter available to consumers was different between the 2 hydrodynamic conditions studied (lagoon and pond). In the absence of any active dynamic flow of waters due to the shallow depth and the influence of the wind that highly determined mixing conditions (Arfi et al. 1993, Smaal \&
Haas 1997), the results for the pond water column and the sediments were very similar. There, different kinds of organic matter (e.g. bivalve egestions) accumulated in the sediments and, depending on their biological cycles, may have become available, through turbulence, to suspension consumers. Such a framework is consistent with the composition of the pond's POM, composed of sedimentary materials $(80 \%)$, while the one true pelagic component, the phytoplankton, accounted for only about $20 \%$. Thus, the resuspension may be able to 'extract' the organic matter accumulated in the sediments from the bottom (Sarà et al. 2003). This 'overexposure mechanism' would allow SOM to re-enter into the water column and thereby increase the likelihood that consumers in the water column can exploit the sedimentary particles. Such a finding is supported by the suggestion that resuspension is considered a primary factor for re-distributed organic resources in coastal environments (Smaal \& Haas 1997). In contrast, under the dynamic flow experienced in the lagoon, despite its shallow depth $(\sim 1 \mathrm{~m})$, the water column and sediments, surprisingly, appeared to be divergent. In fact, the POM in the lagoon was represented mainly by isotopic signatures of phytoplankton, similar to a deeper pelagic environment where the bottom contribution is negligible. Even though a partial contribution of the bottom could be represented by organic matter from sessile algae, the total sedimentary contribution to the POM was less than half the phytoplankton's. Indeed, in shallow environments, a zero contribution of the bottom products to the water column dynamics has to date not been reported. Such results suggest that the 

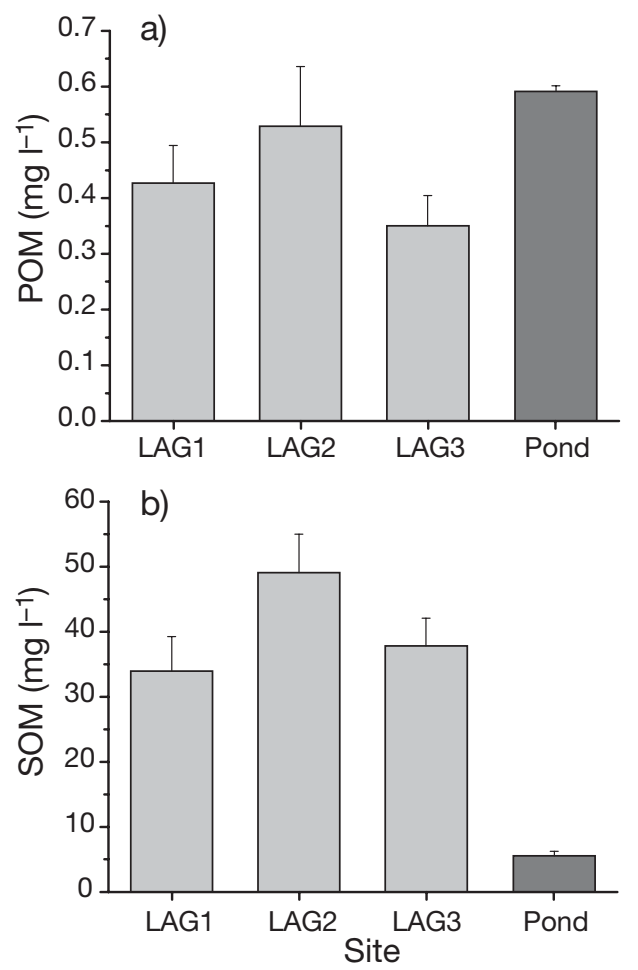

Fig. 3. Particulate (POM, $\mathrm{mg} \mathrm{l}^{-1}$; a) and sedimentary (SOM, $\mathrm{mg} \mathrm{g}^{-1} ;$ b) organic matter concentrations in lagoon $\left(\mathrm{LAG}_{1}\right.$, $\mathrm{LAG}_{2}, \mathrm{LAG}_{3}$ ) vs. pond

hydrodynamics (prevailing conditions of lateral movements of water masses) acted as if almost mechanically uncoupling the 2 realms (pelagic and benthic), while the water column behaved as a lamina, slowly streaming on the bottom and only partially scoring its sedimentary organic content. As a result, the SOM in the lagoon was mostly affected by the signature of seagrasses' detritus, almost totally accumulating in the sediments. Thus, although a scant quota of sedimentary particles could be extracted from the sediments in the lagoon, resuspended particles underwent lateral drifting transport moving them far away to accumulation sites or to the adjacent sea (La Loggia et al. 2004). This could minimise the trophic role of resuspended sedimentary products to the lagoon water column. In contrast, in the pond the contribution of seagrasses to the SOM was truly negligible (about tenfold less), because local turbulence did not allow its sedimentary accumulation.

\section{Causes of differences in OM quality and quantity between closed and open areas}

The POM chl a concentration was lower in the lagoon than in the pond, while the SOM chl a concentration was not significantly different. The prevalent
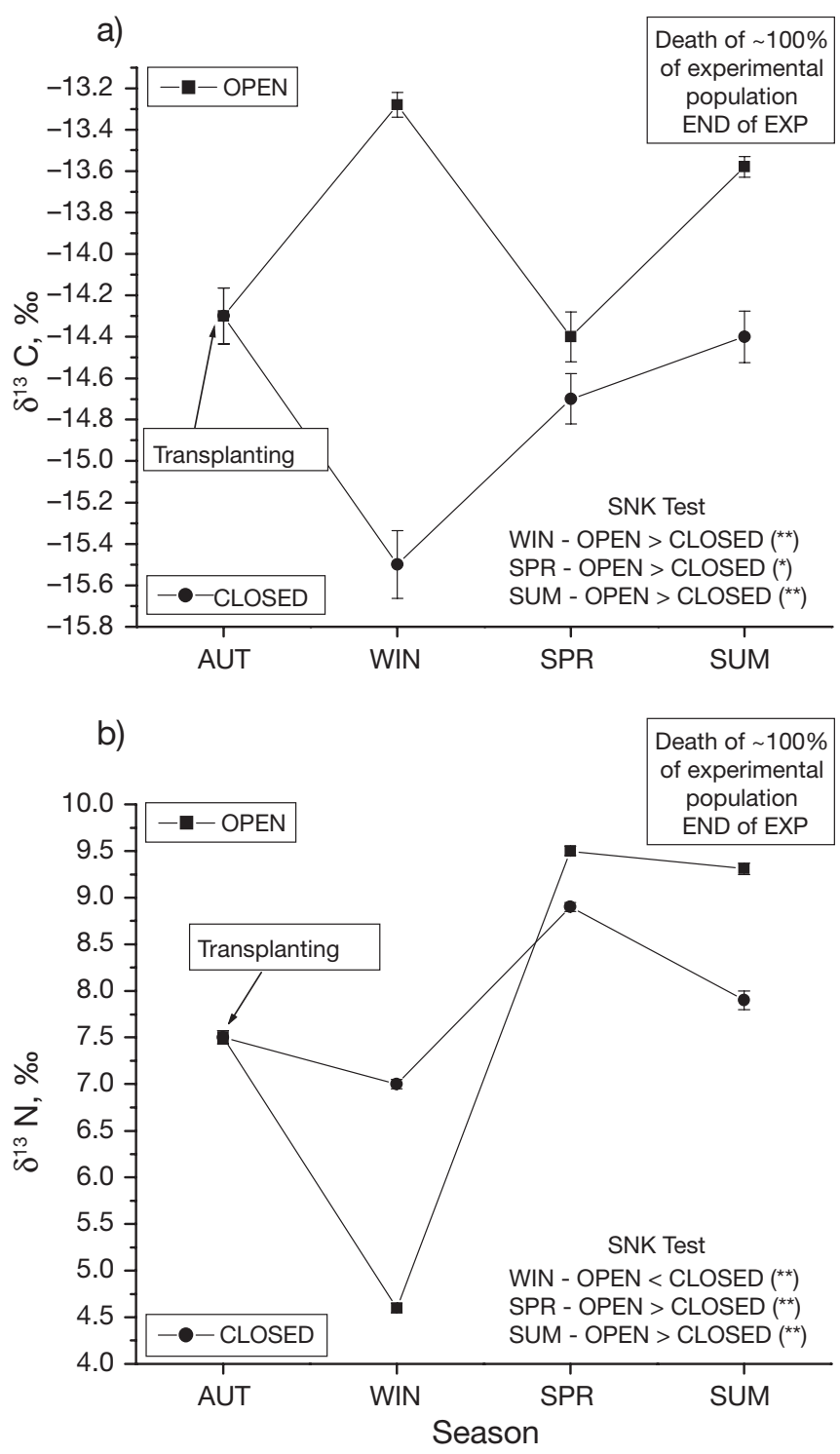

Fig. 4. Brachidontes pharaonis. Stable carbon $\left(\delta^{13} C_{i}\right.$ a) and nitrogen $\left(\delta^{15} \mathrm{~N}_{i}\right.$ b) seasonal composition of natural (POND; a) and transplanted (LAGOON; b) populations

mixing conditions inside the pond might play a dual role in explaining these different results: (1) they might lead to a general increase of dissolved nutrient levels (Smaal \& Haas 1997), enhancing microplankton biomass (Wainright \& Hopkinson 1997) and (2) they could lead to the resuspension of sand microflora enriching the water column with highly labile sedimentary detritus. In contrast, in the lagoon the phytoplankton, when unable to find optimal conditions to increase its biomass due to the low nutrient concentrations, made those waters more markedly oligotrophic, typically like the adjacent Mediterranean waters (Sarà et al. 1999). Proteins and carbohydrates were also different between the lagoon and the pond, being higher in the 
pond and lower in the lagoon as regards to the POM and conversely to the SOM. The pond's labile organic matter accumulated in the sediments, and once it was removed by resuspension, it was made available to the water column enriching it with labile compounds available for suspension feeders. As a main consequence, their concentrations in the sediments were lower than the lagoon's sediments, because the resuspension could enhance the displacement to the water column lowering their concentrations to undetectable limits. In the lagoon, the labile compounds produced on the bottom remained trapped in the sediments. As a result, in the Marsala lagoon the concentrations of total (Sarà et al. 1999) and labile (Pusceddu et al. 1997, 2003) sedimentary organic matter have been measured to a hitherto unprecedented degree in the Mediterranean literature.

\section{The response of suspension feeders to the 2 different hydrodynamic conditions}

One of the objectives of the present study was to validate the hydrodynamic hypothesis with a manipulative experiment based on the comparison of the isotopic composition of natural mussels living in the pond to specimens of the same species transplanted to the lagoon. However, this experiment could not be planned with canonical experimental procedures (e.g. replication of pond closed system), because Brachycomes pharaonis, since its first recording in 1989 (Sarà et al. 2000), is currently present only in the studied pond, and the entire Western Sicilian Saltworks System comprises 30 ponds. This apparent anomaly in the distribution of this mussel is currently the focus of a massive research effort. The present results were, however, deemed sufficient to substantiate the main hypothesis of this study. Immediately after the displacement from the closed pond to the open lagoon, the transplanted mussels showed a sharp scattering of the isotopic signatures compared to those of the mussels in the pond, adjusting their isotopic composition within $90 \mathrm{~d}$ and adapting their diet to the available resources of the new environment. Such a finding agrees with earlier reports about the complete acclimatization of enzyme activity in transplanted Perna viridis, which was observed 90 d after the transplantation (Wong \& Cheung 2003). Indeed, lagoon mussels face new trophic conditions, displaying isotopic compositions differently to mussels living in the pond. Pond mussels exploited, at their peak, the whole spectrum of the trophic availability, mainly of sedimentary provenance, and their own pseudofaecal material was the main item in their diet. This suggests that the level of food supply to mussels in the pond was so high that B. pharaonis reached and exceeded the threshold of pseudofaecal production (Griffiths \& King 1979a, Griffiths \& Griffiths 1987, Hawkins \& Bayne 1992, Sarà et al. 2000). Pseudofaeces accumulates in the sediments and possibly returns to mussels through resuspension, representing the main protein-rich resource in their diet (Dame 1996, Sarà et al. 2003). In contrast, the transplanted mussels could rely only on pelagic organic matter for their diet because of the aforementioned uncoupling of the water column and the sediments. Thus, in the lagoon the sessile suspension consumers, under oligotrophic regimes, were forced to exploit a variety of organic sources that were highly unpredictable over time (e.g. phytoplankton and algae detritus) (Norkko et al. 2000). These sources were too aleatory to feed mussels and were likely not sufficient to sustain their biomass production. Similar findings have been reported frequently in the current literature; it has been observed that in wave-exposed shores the wave action limited the food supply to Mytilus galloprovincialis and consequently their growth was limited (Steffani \& Branch 2003). Consequently, almost all of the transplanted mussels died after only $270 \mathrm{~d}$. It would appear that the lagoon conditions were not favourable as a habitat for suspension feeders and that the food supply was too scarce to sustain the mussel scope for growth. Thus, sedimentary OM, which in the pond represented the most important source of food supply, was not present in the lagoon, and this affected the response of filter feeders, reducing the chance of their occurrence.

In conclusion, mussels in the pond could exploit, over time, organic matter produced in loco, continually rearranged in loco by means of wind-driven resuspension and consumed in loco with an efficiency able to sustain a massive secondary production. Under lagoon conditions, the benthic and pelagic habitats were uncoupled, which made it appear that each had its own independent 'status' with its own dynamics and productions. This in turn would reduce the suitability of this habitat for high levels of secondary production.

Acknowledgements. The author thanks Prof. L. BenedettiCecchi, University of Pisa, Italy, Dr. D. Campobello, University of Manitoba, Canada, Dr. G. Ceccherelli, University of Sassari, Italy, Prof. A. Pusceddu, University of Ancona, Italy, 2 anonymous referees for their comments improving the earlier version of the manuscript and Dr. L. D'Amelio, Geokarst Inc., Trieste, Italy, for his kind help in analysing the isotopic samples.

\section{LITERATURE CITED}

Arfi R, Guiral D, Bouvy M (1993) Wind induced resuspension in a shallow tropical lagoon. Estuar Coast Shelf Sci 36: 587-604

Ceccherelli G, Casu D, Sechi N (2005) Spatial variation of intertidal assemblages at Tavolara-Capo Coda Cavallo MPA (NE Sardinia): geographical vs. protection effect. Mar Environ Res 59:533-546 
Dame RF (1996) Ecology of marine bivalves: an ecosystem approach. CRC Press, Boca Raton, FL

Denny MW (1988) Biology and mechanics of the wave-swept environment. Princeton University Press, Princeton, NJ

Ekman JE, Peterson CH, Cahalan JA (1989) Effects of flow speed, turbulence and orientation on growth of juvenile bay scallops Argopecten irradians concetricus (Say). J Exp Mar Biol Ecol 132:123-140

Emerson CW (1990) Influence of sediment disturbance and water flow on the growth of the soft-shell clam, Mya arenaria L. Can J Fish Aquat Sci 47:1655-1663

Fabiano M, Sarà G, Mazzola A, Pusceddu A (2001) Environmental constraints on pathways of organic detritus in a semi-enclosed marine system (W Mediterranean). In: Faranda FM, Gugliemo L, Spezie G (eds) Mediterranean ecosystems: structure and processes. Springer-Verlag, Berlin, p 436-445

Griffiths CL, Griffiths RJ (1987) Bivalvia. In: Pandian TJ, Vernberg FJ (eds) Animal energetics. Academic Press, New York, p 1-88

Griffiths CL, King JA (1979a) Some relationships between size, food availability and energy balance in the ribbed mussel Aulacomya ater. Mar Biol 51:141-149

Hawkins AJS, Bayne BL (1992) Physiological interrelations, and the regulation of production. In: Gosling $\mathrm{E}$ (ed) The mussel Mytilus: ecology, physiology, genetics and culture. Elsevier, Amsterdam, p 171-222

Hicks DW, Tunnell JW Jr, McMahon RF (2001) Population dynamics of the nonindigenous brown mussel Perna perna in the Gulf of Mexico compared to other world-wide populations. Mar Ecol Prog Ser 211:181-192

Judge ML, Coen LD, Heck KL Jr (1992) The effect of longterm alteration of in situ currents on the growth of Mercenaria mercenaria in the Northern Gulf of Mexico. Limnol Oceanogr 37:1550-1559

La Loggia G, Calvo S, Ciraolo G, Mazzola A, Pirrotta M, Sarà G, Tomasello A, Vizzini S (2004) Interdisciplinary approach to assess the influence of hydrodynamic conditions on the production and fate of Posidonia oceanica (L.) Delile in a semienclosed shallow basin (Stagnone di Marsala, Western Sicily). Chem Ecol 20:183-201

Lenihan HS, Peterson CH, Allen JM (1996) Does flow speed also have a direct effect on growth of active suspensionfeeders: an experimental test on oysters. Limnol Oceanogr 41:1359-1366

Norkko J, Bonsdorff E, Norkko A (2000) Drifting algal mats as an alternative habitat for benthic invertebrates: species specific responses to a transient resource. J Exp Mar Biol Ecol 248:79-104

Editorial responsibility: Kenneth Heck (Contributing Editor), Dauphin Island, Alabama, USA
Phillips DL, Gregg JW (2003) Source partitioning using stable isotopes: coping with too many sources. Oecologia 136: 261-269

Pusceddu A, Sarà G, Mazzola A, Fabiano M (1997) Relationships between suspended and sediment organic matter in a semi-enclosed marine system: the Stagnone di Marsala sound (Western Sicily). Water Air Soil Pollut 99:343-352

Pusceddu A, Dell'Anno A, Danovaro R, Manini E, Sarà G, Fabiano M (2003) Enzymatically hydrolyzable protein and carbohydrate sedimentary pools as indicators of the trophic state of 'detritus sink' systems: a case study in a Mediterranean coastal lagoon. Estuaries 26:641-650

Sarà G, Leonardi M, Mazzola A (1999) Spatial and temporal changes of suspended matter in relation to wind and vegetation cover in a Mediterranean shallow coastal environment. Chem Ecol 16:151-173

Sarà G, Romano C, Caruso M, Mazzola A (2000) The new Lessepsian entry Brachidontes pharaonis (Fischer P., 1870) (Bivalvia, Mytilidae) in the Western Mediterranean: a physiological analysis under varying natural conditions. J Shellfish Res 19:967-977

Sarà G, Vizzini S, Mazzola A (2003) Sources of carbon and dietary habits of new Lessepsian entry Brachidontes pharaonis (Bivalvia, Mytilidae) in the western Mediterranean. Mar Biol 143:713-722

Sarà G, Scilipoti D, Milazzo M, Modica A (2006) Use of stable isotopes to investigate dispersal of waste from fish farms as a function of hydrodynamics. Mar Ecol Prog Ser 313: $261-270$

Smaal AC, Haas HA (1997) Seston dynamics and food availability on mussel and cockle beds. Estuar Coast Shelf Sci 45:247-259

Steffani CN, Branch GM (2003) Growth rate, condition, and shell shape of Mytilus galloprovincialis: responses to wave exposure. Mar Ecol Prog Ser 246:197-209

Underwood AJ (1997) Experiments in ecology. Their logical and interpretation using analysis of variance. Cambridge University Press, Cambridge

Wainright SC, Hopkinson CS Jr (1997) Effects of sediment resuspension on organic matter processing in coastal environments: a simulation model. J Mar Syst 11:353368

Wildish D, Kristmanson D (1997) Benthic suspension feeders and flow. Cambridge University Press, Cambridge

Wong WH, Cheung SG (2003) Site-related differences in the feeding physiology of the green mussel Perna viridis: a reciprocal transplantation experiment. Mar Ecol Prog Ser 258:147-159

Submitted: May 6, 2005; Accepted: June 7, 2006

Proofs received from author(s): December 8, 2006 